\title{
Beauty in Eco-Technology - A Sewage Treatment Plant as a Spatially Attractive Structure
}

\author{
Agnieszka Wójtowicz-Wróbel ${ }^{1 *}$ \\ ${ }^{1}$ Facutly of Architecture, Cracow University of Technology, 31-155 Krakow, Poland
}

\begin{abstract}
The increasing awareness of the protection of depleting natural resources results in new challenges for us to face. The necessity to treat domestic water is one of such basic challenges. The intensive development of modern technological solutions in this field creates new possibilities including those related to the architectural shaping of structures. Simultaneously - following the example of other municipal infrastructure buildings - thanks to the development of technology - sewage treatment plants become structures that are more accessible and spatially attractive. The goal of this article is to answer the question whether these types of urban engineering elements can constitute a structure that is spatially attractive in terms of the tissue of urban and suburban areas, and if so, then under what conditions? The study was performed using a method of analysing a selection of structures in Poland (the first part of the article), in addition to an analysis of examples of good practice regarding such projects in other countries, which constitute state of the art aesthetic solutions in this regard (the second part of the article). The result of the study will allow finding the answer to the question: what is it that causes some sewage treatment plants to have the opportunity to become a significant spatial element, while others only fulfil their technological functions? The results of the analyses performed by the author could form the basis for performing comparative studies of this scope on other examples, including both sewage treatment plants, as well as other municipal infrastructure buildings of a city.
\end{abstract}

\section{Introduction}

Increasing awareness of the necessity to protect the environment brings new challenges. These challenges can be perceived in a multi-planar manner, and can be discussed in three groups of problems:

- Protection - the direct protection of animate and inanimate nature, the protection of areas, ecosystems, habitats, species and other elements, but also the protection of the broadly understood landscape,

\footnotetext{
* Corresponding author: awojtowicz@pk.edu.pl
} 
- Appropriate use - this is the proper use (as much as it is possible and beneficial) of resource deposits, supplies and values. Of particular importance in this aspect is the matter of the circulation economy and its supplementary concept of "cradle to cradle", based on treating a used product as material for the production of a new one.

- Education - increasing the awareness of residents concerning matters of nature, pro-environmental actions implemented in everyday life and the propagation of new solutions in pro-environmental matters, which appear along with the development of science and technology.

The beauty of preserved nature and that of natural landscapes is an element that is clearly identifiable and, in terms of the general concept of beauty - one that is obvious. The beauty of cities is equally identifiable. However, the broadly understood beauty of cities is not solely the beauty of their interior - of meticulously maintained historical old towns or modern districts saturated with works of contemporary architecture. Can external areas of cities be beautiful? Can industrial areas be considered beautiful? The urban regeneration of post-industrial areas (including areas of a city's engineering services infrastructure) and their adaptation to new forms of use - of a commercial, residential or other character - is currently a commonly employed practice. We appreciate their raw, industrial character, one that is interesting and often so different from the widely accepted canon of beauty. However, can newly built structures of the technical infrastructure of a city, such as thermal waste processing plants or sewage treatment plants, which provide municipal services first and foremost, also be visually attractive and is their design as visually attractive structures a significant matter?

This article is a part of a cycle of publications concerning structures which fulfil new, pro-environmental functions within cities. The research conducted as a part of this cycle concerns two types of structures:

- Pro-environmental structures used to process municipal waste,

- Structures associated with the reuse of water (mainly sewage treatment plants, but also water purification plants).

Concerning the two abovementioned groups of structures, the research performed by the author has been divided into five types of problems:

- Social significance and reception,

- Architecture and beauty,

- Location and accessibility,

- Spatial relations within urban and suburban structures,

- Technical and technological matters in relation to architectural aspects.

The research has been presented as a scheme with the structure of a matrix (table 1), which was also used in the case of architectural studies, as well as those concerning urban design and planning (cf. [1]).

Table 1. Scheme of the research being performed using the structure of a matrix.

Original work, 2017.

\begin{tabular}{|l|l|l|l|l|l|}
\hline & Social & Architecture & $\begin{array}{c}\text { Locations/ } \\
\text { Accessibility }\end{array}$ & $\begin{array}{c}\text { Urban } \\
\text { Relations }\end{array}$ & $\begin{array}{c}\text { Technical } \\
\text { Issues }\end{array}$ \\
\hline $\begin{array}{l}\text { Thermal } \\
\text { Waste } \\
\begin{array}{l}\text { Processing } \\
\text { Plants }\end{array}\end{array}$ & S/TWPP & A/TWPP & L/TWPP & U/TWPP & T/TWPP \\
\hline $\begin{array}{l}\text { Wastewater } \\
\text { Treatment } \\
\text { Plant }\end{array}$ & S/WTP & $\underline{\mathbf{A} / W T P}$ & L/WTP & U/WTP & T/WTP \\
\hline
\end{tabular}


So far, the cycle has featured the publication of studies concerning thermal waste processing plants. Furthermore, supplementary studies are also being carried out outside of the cycle, and which will be somewhat of a backdrop for the main line of research. They cover detailed studies of interesting cases of the aforementioned structures or references to futuristic design visions of ecological significance.

\section{Studies concerning sewage treatment plants in Poland}

Poland's accession into the structures of the European Union on 1 May 2004 [8] created new chances for economic development, but also new constraints and requirements. These requirements are linked with the protection of nature to a considerable extent. This refers to the direct protection of species or areas, as well as to such spatial and economic activities that halt the negative influence of everyday life on the environment. Poland entered the structures of the European Union nearly thirty years after the drafting of the Stockholm declaration in 1972. This document is treated as the start of intensive efforts towards a global increase of environmental awareness [2]. For this reason, Poland, when entering the structures of the European Union, became able to draw on the numerous experiences of the other partners in terms of environmental protection. Currently, after fourteen years of membership, Poland must adapt to the legal framework concerning environmental protection $[3,4]$ in accordance with seven horizontal problems:

- evaluation of impact on the natural environment,

- access to information about the natural environment,

- participation of society in the protection of the natural environment,

- integrated permits,

- the environmental management and assessment system (EMAS)

- ecological branding of products,

- responsibility for damage to the environment.

These issues refer to the primary sections of law, as well as to particularly essential detailed issues, such as the protection of waters, waste management, protection from air pollution, climate protection or environmental protection. Problems concerning the activity of sewage treatment plants are at the point of contact of many of the abovementioned sections. Legal documents that regulate the operation of sewage treatment plants govern not only the neutralisation of sewage or even the broadly understood protection from air pollution. Poland, as one of the EU member states, is adapting its legal regulations to EU law in these matters as well. Increasing environmental awareness, in addition to broader and more effective efforts towards protecting the environment, also lead to transformation in visual terms. This is particularly evident on the architectural plane. New possibilities that are being provided by technology - in this case that of wastewater treatment and water purification - provide new opportunities concerning the significance of such technological structures both in the visual aspect (of the structures themselves), as well as from a spatial perspective (impact on the surrounding space). However, is Poland, making use of these opportunities in line with these possibilities?

Due to the structure of the research cycle, the study was carried out in those cities in which a wastewater treatment plant of supralocal significance either already operated or was going to start operating in the near future. In line with built projects in other European countries, structures of this type are being placed in each other's vicinity (as much as possible), which does have some benefits, but also causes some inconveniences. The study covered nine cities and focused on the performance of an evaluation of the visual significance of sewage treatment plants. The study was performed in the following cities: Gdańsk, Konin, Kraków, Poznań, Rzeszów, Szczecin and Warsaw. The type of employed technological infrastructure necessary in the process of wastewater treatment and water 
purification has been presented in table 2 , in addition to the number of these structures within the aforementioned cities.

Table 2. Municipal engineering service facilities involving sewage treatment and water purification in selected Polish cities, original work 2018.

\begin{tabular}{|l|l|l|}
\hline \multicolumn{1}{|c|}{ City } & Population[7] & \multicolumn{1}{c|}{ Sewage treatment and water purification plants } \\
\hline Białystok & 296628 & $\begin{array}{l}\text { - water purification plant - 2x } \\
\text { - water supply network facility, sewage utility facility } \\
\text { - sewage treatment plant 1x }\end{array}$ \\
\hline Bydgoszcz & 354990 & $\begin{array}{l}\text { - water purification plant - 2x } \\
\text { - water supply network facility, sewage utility facility } \\
\text { - sewage treatment plant 1x }\end{array}$ \\
\hline Gdańsk & 464293 & $\begin{array}{l}\text { - water purification plant and storage reservoirs - 9x } \\
\text { - water supply network facility, sewage utility facility } \\
\text { - sewage treatment plant 1x }\end{array}$ \\
\hline Konin & 75607 & $\begin{array}{l}\text { - water purification plant - 4x } \\
\text { - water supply network facility, sewage utility facility } \\
\text { - sewage treatment plant 2x }\end{array}$ \\
\hline Kraków & 767348 & $\begin{array}{l}\text { - water purification plant - 4x } \\
\text { - water supply network facility, sewage utility facility } \\
\text { - sewage treatment plant 2x }\end{array}$ \\
\hline Poznań & 539549 & $\begin{array}{l}\text { - water purification plant - 2x } \\
\text { - water supply network facility, sewage utility facility } \\
\text { - sewage treatment plant 1x }\end{array}$ \\
\hline Rzeszów & 190013 & $\begin{array}{l}\text { - water purification plant -1x } \\
\text { - water supply network facility, sewage utility facility } \\
\text { - sewage treatment plant 1x }\end{array}$ \\
\hline Szczecin & 404878 & $\begin{array}{l}\text { - water purification plant -5x } \\
\text { - water supply network facility, sewage utility facility } \\
\text { - sewage treatment plant 2x }\end{array}$ \\
\hline
\end{tabular}

All of the analysed cities (except Konin) are cities which fulfil the function of a voivodship capital, as well as - on the scale of Poland - being large cities. In this category - excluding the much smaller Konin - their populations vary: from Rzeszów, which is located in the south east of Poland, in one of the least economically developed voivodships, and has 200 thousand inhabitants, to the nearly two million inhabitants of Warsaw, the state capital. The listing presented above only includes municipal, communal and intercommunal companies that are the owners or co-owners of water supply and sewerage network systems, being the main water suppliers in their respective cities. Facilities belonging to private companies, which provide water supply and sewerage-related services on the basis of agreements, as well as those structures, which (even when belonging to an inter-communal company - e.g. like in Poznań) are located outside of a city's limits, were not taken into consideration. Including all such structures in the study would have provided a false image in terms of the spatial structures of cities. It should be highlighted that the presented table listing has the character of a review in terms of the spaces of cities. After a detailed analysis of the water supply and sewerage system infrastructure in each city, it was concluded that there are differences that significantly affect the results of the study at the 
level of the division of the economic structure. The data that was obtained only refers to the structure of a company, while there is a lack of technical data concerning the technological advancement of individual plants, their effectiveness or size [9] - qualities which considerably affect the number of sewage treatment plants or water purification plants in the given cities. Nevertheless, the listing of the aforementioned structures, even without detailed technical data, provides an image of the problem on the scale of the city in terms of space, which can be used for further analyses concerning visual matters - which constitute a basis for further research. Detailed studies concerning the technologies employed at sewage system facilities, from the point of view of planning and urban design, will be discussed in a separate article as a part of this series, which will address these types of problems.

A sewage treatment plant belonging to a municipal company, water purification sites (in cases in which it was not possible to find data concerning solely water purification plants, they have been listed along with storage reservoirs, as highlighted in the table) and a sewage system were present in each of the cities under discussion. It can be observed that the number of sewage treatment plants, when analysing the nine cities selected as examples, is not dependent on their population - a greater number of water purification sites was present in the smallest city, Konin, than in Warsaw, which is the largest. The effectiveness of the individual plants, their technological solutions, dependent on, among other things, the individual natural properties of each city (shape of the terrain, the river network and water relations, etc.), as well as the division of the administrative structure within municipal companies which treats some plants as individual entities while combining others into a single entity, was observed to be of a greater significance here. As in the case of sewage treatment plants in which the structural division of a company had no effect on the physical dimension, in the case of water purification sites this situation presented itself in a vastly different manner. Significant differences were also observed in technological matters, both between individual cities, as well as between individual plants belonging to the same municipal company. Undoubtedly, Poland's membership in EU structures and the possibilities of obtaining funding through EU subsidies significantly affected the technological solutions being used, enabling the modernisation of existing plants and installations or the construction of new ones.

It can be observed that, from a spatial point of view, every city listed in the table featured two types of structures, whose significance in terms of their massing can be spatially significant (water purification plant, sewage treatment plant), as well as two linear elements, which have an intensive, yet indirect influence on the development of the spaces of cities (the water supply and sewage systems). Sewage treatment plants from each city were analysed, with the analysis presented in table 3 . The evaluation included the compositional values of the entirety of their layouts, as well as an evaluation of their architectural elements (structures, buildings). Analyses were performed on 13 sewage treatment plants located in 9 cities. In the case of the aesthetic and compositional analysis of the sites, elements taken into consideration included both the mutual compositional relations between each engineering and administrative structure, as well as the site development itself, taking into consideration natural and arranged greenery, its maintenance, as well as the manner of composing paved surfaces and street furniture, in cases where such elements were present. The sites were evaluated on a three-point scale: $\bullet \bullet \bullet$ - areas of high quality, spatially composed and aesthetically well-maintained, creating a single, compositionally coherent whole with their architectural structures and arranged greenery. Group $\bullet \bullet$ are complexes of average aesthetic and compositional value designed, yet not presenting significant value. Group $\bullet$ are areas in which the placement of individual elements was observed to be random in terms of their composition. These areas were most often maintained in good technical condition and a general orderliness, yet they 
featured a lack of compositional thought. The evaluation of the architectural value of the structures was also performed in three tiers. Group $\bullet \bullet \bullet$ are structures with the greatest architectural value. In this case the evaluation took into consideration the architectural value of a structure, in addition to focusing on the utilisation of the specificity of the function of the structure as an inspiration for architectural design. Group $\bullet \bullet$ includes buildings with average architectural values, and in which a creative idea and an attempt at composing the massing were nevertheless visible. Group • included structures with the lowest aesthetic value. These were mostly buildings whose architecture was limited to constituting a "technical installation envelope" (in the case of technological structures), while administrative buildings could have been described as construction solutions characterised by insignificant architectural value.

Table 3. Selected elements of the engineering infrastructure of a city in terms of sewage treatment evaluation of the compositional values of a layout and the architectural values of its buildings, original work 2018.

\begin{tabular}{|c|c|c|c|}
\hline City & Plant name & $\begin{array}{l}\text { Site development } \\
\text { aesthetic and } \\
\text { compositional } \\
\text { value rating }\end{array}$ & $\begin{array}{l}\text { Building } \\
\text { architectural } \\
\text { value rating }\end{array}$ \\
\hline Białystok & $\begin{array}{l}\text { Białystok Waterworks Sewage } \\
\text { Treatment Plant }\end{array}$ & $\bullet$ & - \\
\hline Bydgoszcz & Fordon Sewage Treatment Plant & - & - \\
\hline Gdańsk & $\begin{array}{l}\text { Gdańsk East Sewage Treatment } \\
\text { Plant }\end{array}$ & $\bullet$ & $\bullet$ \\
\hline \multirow[b]{2}{*}{ Konin } & $\begin{array}{l}\text { „Right Bank” Sewage Treatment } \\
\text { Plant }\end{array}$ & $\bullet$ & $\bullet$ \\
\hline & $\begin{array}{l}\text { „Left Bank” Sewage Treatment } \\
\text { Plant }\end{array}$ & $\bullet$ & - \\
\hline \multirow[b]{2}{*}{ Kraków } & $\begin{array}{l}\text { „Płaszów” Sewage Treatment } \\
\text { Plant }\end{array}$ & $\bullet$ & $\bullet$ \\
\hline & $\begin{array}{l}\text { „Kujawy” Sewage Treatment } \\
\text { Plant }\end{array}$ & - & - \\
\hline Poznań & $\begin{array}{l}\text { Left Bank Sewage Treatment } \\
\text { Plant }\end{array}$ & $\bullet$ & $\bullet$ \\
\hline Rzeszów & $\begin{array}{l}\text { Sewage Treatment Plant of the } \\
\text { Municipal Water Supply and } \\
\text { Sewerage Company in Rzeszów }\end{array}$ & $\bullet$ & $\bullet$ \\
\hline \multirow[t]{2}{*}{ Szczecin } & $\begin{array}{l}\text { „Pomorzany” Sewage Treatment } \\
\text { Plant }\end{array}$ & $\bullet$ & $\bullet \bullet$ \\
\hline & „Zdroje' Sewage Treatment Plant & - & - \\
\hline \multirow[b]{2}{*}{ Warsaw } & „Czajka” Sewage Treatment Plant & $\bullet$ & $\bullet$ \\
\hline & $\begin{array}{l}\text { „Południe” Sewage Treatment } \\
\text { Plant }\end{array}$ & $\bullet \bullet$ & $\bullet \bullet$ \\
\hline
\end{tabular}

$\bullet \bullet \bullet$ - high aesthetic and compositional / architectural value, $\bullet \bullet$ - average aesthetic and compositional / architectural value, $\bullet$ - low compositional / architectural value.

Based on the research performed concerning site development aesthetic and compositional issues, it can be observed that from among the thirteen sites, none of them met the criteria for the highest rating. Only the "Południe" Sewage Treatment Plant in 
Warsaw was rated as a complex of average value. It is a sewage treatment plant that has been modernised, which also entailed measures involving the composition of the complex and its architecture. It was found not to be a plant with an exceptional urban composition, although a cohesion in terms of design was observable, in addition to a care for detail and greenery, as well as a successful attempt at making compositional references to its form of use. This reference was also observable in its buildings, particularly in the administrative building. At the same time, the buildings of the "Południe" Sewage Treatment Plant were rated as average on the adopted scale, however, in comparison to the buildings of other sewage treatment plants, they positively stand out (in addition to the "Pomorzany" Sewage Treatment Plant located in Szczecin, which was similarly rated). The complexes and buildings that were rated - were rated as sites of low aesthetic and compositional, as well as architectural value. This was the most numerous group in the site development category (12 cases), as well as in the category of buildings (11 cases). These were most often complexes whose design had been focused solely on their technological dimensions, ignoring aesthetic or compositional matters, in which architecture fulfilled solely the function of an "envelope" for the installations and technology of a plant (Fig. 1).

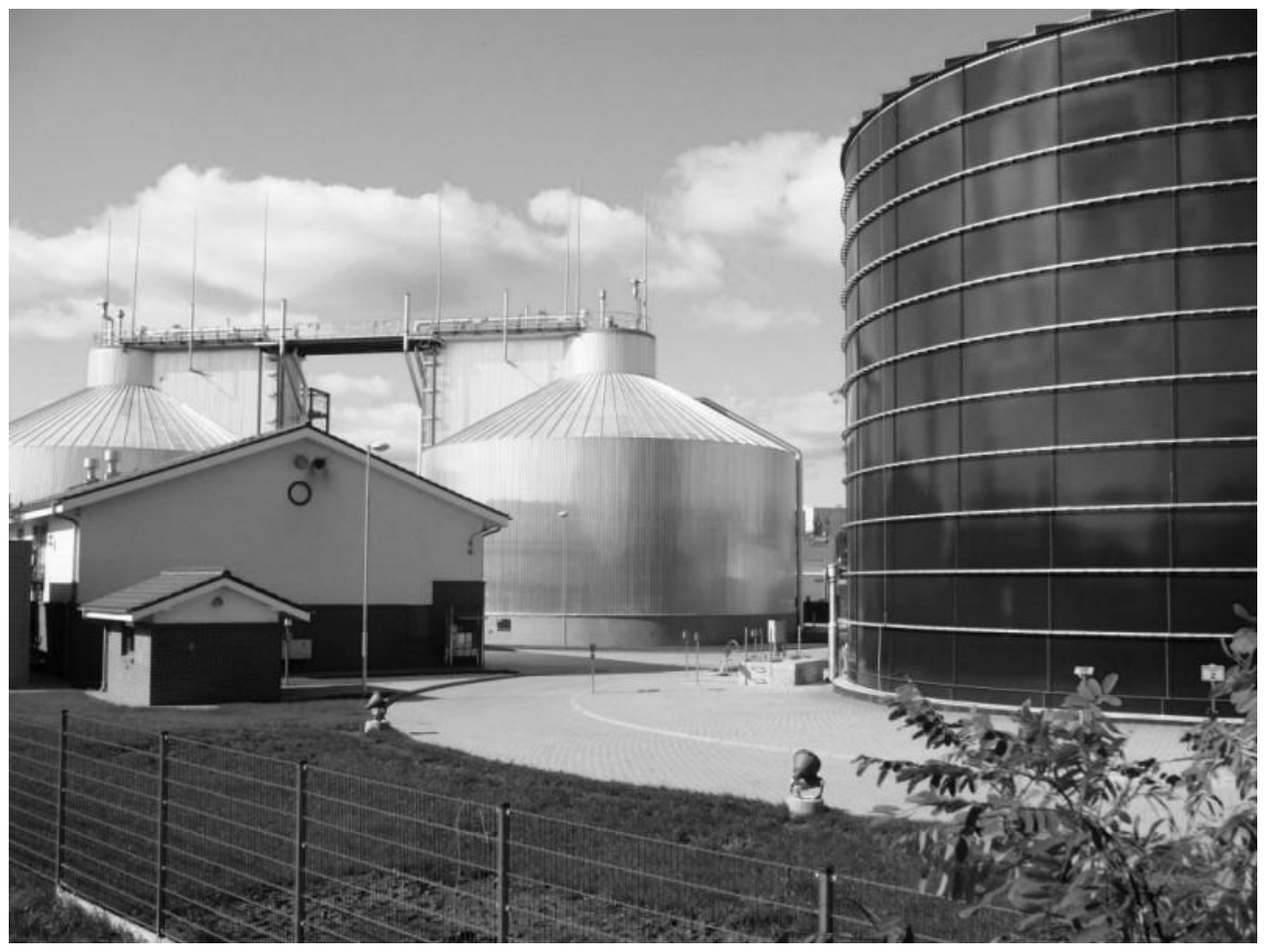

Fig. 1. Lewobrzeżna Oczyszczalnia Ścieków (Left Bank Sewage Treatment Plant) in Poznań [5]

\section{Examples of good practice - the San Claudio waste treatment plant in Spain}

Based on the abovementioned research performed in nine large Polish cities, we can observe that structures which serve as sewage treatment plants are, in general, not attractive in terms of the aesthetic and composition of their site development, as well as from an architectural point of view. In this case, the increase in environmental awareness did not 
lead to an increase in aesthetic awareness. However, examples of efforts in which the construction or redevelopment of an existing wastewater treatment plant entails positive spatial changes and the structures being built blend well with their surroundings and are designed in accordance with the art of architecture do exist. One of such examples is the Wastewater Treatment Plant in San Claudio, Spain (Fig. 2).

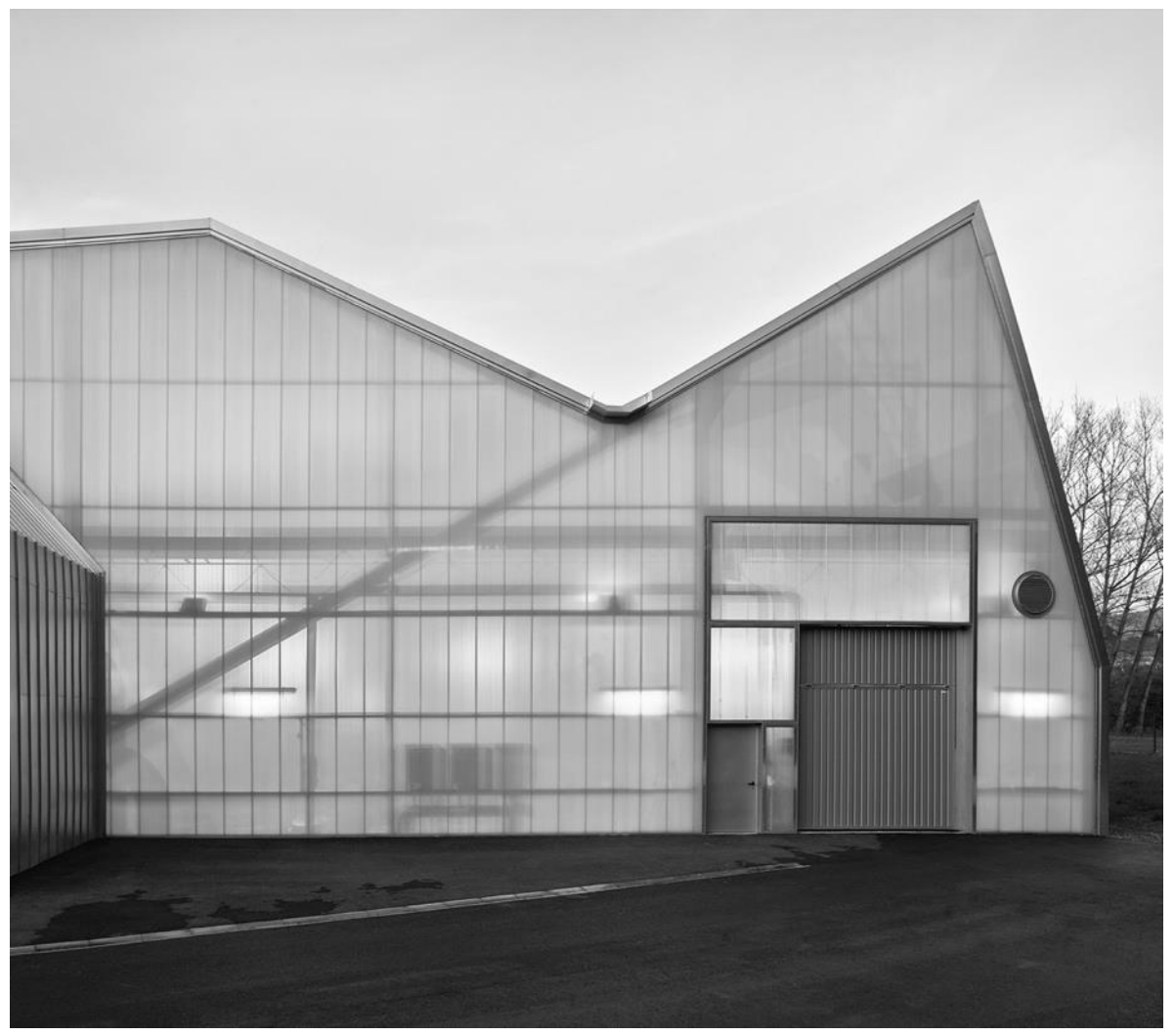

Fig. 2. Wastewater Treatment Plant in San Claudio, phot. By M. Apollonio, 2017 [6]

The structure's current form was built as a part of an extension and modernisation project of an existing wastewater treatment plant. Designed by the Madrid design practice Padilla Nicas Arquitectos, the structure entered use in 2016. The authors of the design are Francisco José Padilla and Juan Manuel Nicás Caballero. As a part of the design task, the designers placed before themselves two challenges. The first stemmed from technological considerations, while the second from conditions related to the site. The layout had to meet strict technological requirements associated with the installation responsible for the treatment of wastewater during all stages, which directly affected the architecture of the buildings, influencing their size. At the same time, due to reasons pertaining to the site, the structures (at least those which were located within the range of an immediate visual evaluation of the surroundings) were supposed to be designed in such a manner as to blend in with the rural tissue, in addition to blending in with the natural conditions (fig, 3). In San Claudio it was possible to overcome the technological challenges, while simultaneously thanks to architectural solutions (through appropriately selected materials, massing and proportions) successfully blend the buildings with the conditions of the site. Thanks to this, the wastewater treatment plant fulfils its function by serving the residents on the one hand, while on the other it is well adapted to its environment, in addition to constituting an 
interesting example of aesthetically pleasing architecture that stands out through its individualism.

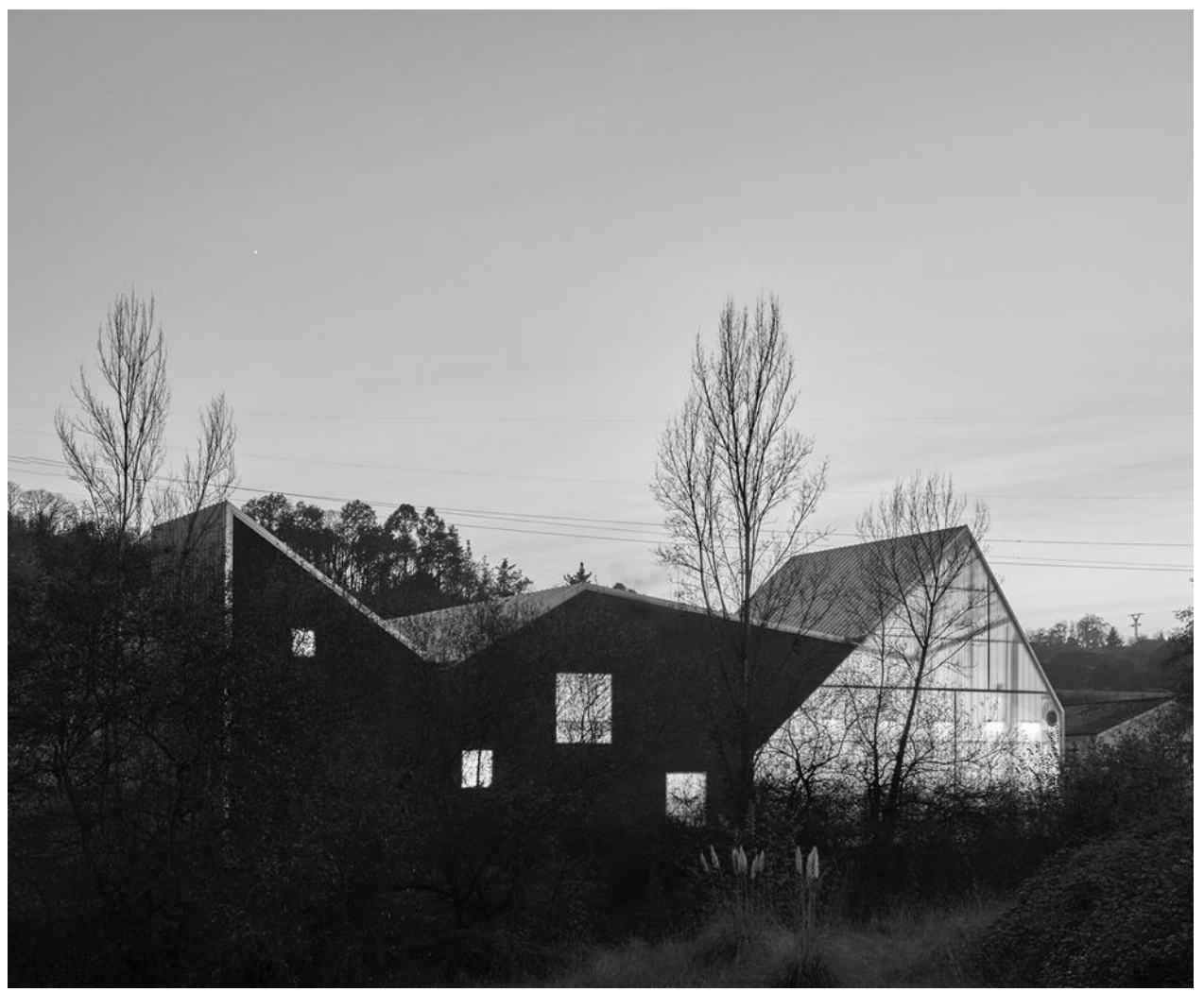

Fig. 3. The structures of the San Claudio Wastewater Treatment Plant, which are a new interpretation of local traditions, phot. by M. Apollonio, 2017 [6]

\section{Conclusions and observations}

The increasing awareness concerning environmental protection, as well as the necessity to depart from managing natural resources in a linear manner in favour of a circulation economy, bring about spatial changes. One of such changes, forced by the necessity concerning contemporary efforts that are beneficial to the environment, is the construction of sewage treatment and water purification plants. Based on the research concerning sewage treatment plants that had been performed, the following conclusions and observations were formulated:

- It was observed that in Poland there was a lack of sewage treatment plant buildings and complexes that had been built in accordance with the principles of designing works of architecture. In the case of technological structures, the architecture of a buildings focused on its technical envelope, while in the case of administrative buildings which serve a plant, their architecture was observed to be most often limited to strictly technical solutions.

- Sewage treatment plants - just like practically any pro-environmental work of architecture - should be characterised by high quality architecture which blends well with technological solutions. The visual aspect is one of the elements which 
lead to a positive public reception of such a plant and to an increase of its public acceptance.

- Modern technological solutions, which eliminate the inconveniences caused by such structures to their surroundings, should go hand in hand with attractive architectural solutions. A form that is friendly in terms of its reception, one that blends in with new pro-environmental sewage treatment and water purification technologies, can become an attractive element of ecological education in the area in which it is located.

- The design of a complex of structures, apart from adapting them to an appropriate sewage treatment technology and drawing on characteristic local forms, the architectural heritage of the surroundings in which said building complex will be located, can also draw on the natural qualities present in those surroundings in which - for technological reasons - it is being placed in (a river, most often also natural low and tall greenery). The use of these natural elements provides interesting design solutions both on the scale of the structure itself and that of the entire complex (the reflections of the buildings in the water, the introduction of various types of greenery). In the case of sewage treatment or water purification plants, the introduction of elements which are closer to nature is a natural consequence of the placement of such a form of use.

- Due to suburbanisation processes in cities, some of these types of structures, although contemporarily placed mostly in outer zones, will find themselves in residential zones and will constitute their immediate surroundings. It is for this reason that care for the attractiveness of these types of buildings is so essential.

\section{References}

1. B. Podhalański, Technology through scales and its impact: from the metropolitan region to the district's urban form, Urban Planning Architecture \& Design, SGEM 2017, Book 5, 1, 295-302 (2017)

2. M. Gwiazdowicz, M. Sobolewski, Ochrona środowiska w polityce UE, 3, Available from:www.orka.sejm.gov.pl, (retrieved on: 02.02.2018)

3. Z.Bukowski, Prawo ochrony środowiska w Unii Europejskiej, (C.H.Beck, 2007)

4. J. Jendrośka, M. Bar (ed.), Wspólnotowe prawo ochrony środowiska i jego implementacja w Polsce trzy lata po akcesji, (Centrum Prawa Ekologicznego 2009)

5. Source available from: www.aquanet.pl, (retrieved on: 02.02.2018)

6. Source available from: www.padillanicas.net (retrieved on: 02.02.2018)

7. Source available from: www.polskawliczbach.pl (retrieved on: 02.02.2018)

8. A. Domagała, Integracja Polski z Unią Europejską, (WAIP 2008)

9. A. Wałęga, K.Chmielowski, S. Satora, Stan gospodarki wodno-ściekowej w Polsce w aspekcie wdrażania Ramowej Dyrektywy Wodnej, Infrastruktura I Ekologia Terenów Wiejskich, (PAN 2009) 